\title{
PRIEST GEORGE ZEMORA - A SUFFERER IN THE COMMUNIST GULAG
}

Florin DOBREI

\begin{abstract}
In the mid-twentieth century, in an Eastern Europe abandoned by the Western powers beyond the 'Iron Curtain', the Church - the only institution that had the courage to teach a doctrine different than the official 'materialist atheist' one - lived through relentless moments. Beaten, marginalized, ostracized by a 'new society' whose supreme postulate was to create the 'new man' utterly alienated from God, the Church ministers experienced terror and repression (some even death), their only 'fault' being to have confessed, served and followed Christ. All these sufferers - some known, others obscure - have written, through their sacrifice and the courage of their testimony, a golden page in the book of immortality of the Church and the Romanian people. One such sufferer (less known in the specialty historiography) was priest George Zemora from Sebeșel (Alba County), spiritual pastor in two parishes of Hunedoara County, Vulcan I and Lunca, who was arrested and interrogated in 19471948, and then relocated to house arrest in Mănăstirea, Călărași County (1951-1955).
\end{abstract}

Keywords: communist gulag, suffering, atheist ideology, priest George Zemora, Hunedoara County.

\section{Preliminaries}

Among the many Orthodox priests suffering in the Romanian communist Gulag - the Romanian Orthodox Church estimates that between 1948 and 1964, one in four priests were arrested, interrogated and sentenced; namely, of the approximately 12,000 existing clergy at the time, about 3,000 of them knew and lived the regime of the prison camps.

Senior Lecturer, "Eftimie Murgu" University (Faculty of Social Sciences), Reşiţa, Romania. 
Some 1,800 died in unimaginable conditions ${ }^{1}-$ among them there were more than thirty clerics from Hunedoara ${ }^{2}$.

The first wave of arrests was recorded in the months from March to August 1945. The suspects, accused of belonging to the Legionary Movement, were imprisoned in the camp at Caracal (Olt county); released shortly thereafter, they remained in the attention of the authorities. Under charges of 'possession of fascist publications', the arrests resumed in the spring of 1946, on the background of the process of Marshal Ion Antonescu; moderated for a moment by Prime Minister Petru Groza, the son of a priest from Hunedoara (born in Băcia) and member of the Diocesan Synod of the Archdiocese of Sibiu (1911-1958). ${ }^{3}$ After 1948, there were constant, massive waves of arrests recorded between 19491952 and 1956-1959. The investigations continued even after 1964, the year of general amnesty for all political prisoners in Romania.

\section{Priest George Zemora - biographical data}

To the list of suffering clergy from Hunedoara must also be added the priest George Zemora; who was priest in the parishes of Vulcan (Petrosani Deanery) and Lunca (Brad Deanery), whose life, service, and - above all - drama will be outlined, especially based on documents stored in the Archive of the Archdiocese of $\mathrm{Arad}^{4}$. From the beginning, it

${ }^{1}$ Ioan DuRĂ, "Ierarhi ai Bisericii Ortodoxe Române îndepărtaţi din scaun şi trimişi în recluziune monastică de către autorităţile comuniste în anii 1944-1981", in Altarul Banatului, no. 10-12/2002, p. 35.

${ }^{2}$ Vasile Manea, Preoţi ortodoç̧i în închisorile comuniste, $3^{\text {rd }}$ ed., Alba Iulia, Edit. Reîntregirea, 2004, passim; Gabriel BASA, "Preoţi, teologi şi călugări hunedoreni în închisorile comuniste", in Altarul Banatului, no. 4-6/2005, p. 72-85; Cicerone IonițoIU, Victimele terorii comuniste. Arestaţi, torturaţi, întemniţaţi, ucişi. Dicţionar, Bucureşti, Edit. Maşina de scris, 2000, passim; Florin DOBREI, Istoria vieții bisericești a românilor hunedoreni, Reșița, Edit. Eftimie Murgu, 2010, p. 585-592; Pavel VESA, Clerici arădeni și hunedoreni deținuți politici (1945-1989), Deva, Edit. Episcopiei Devei și Hunedoarei, 2014, passim; Adrian Nicolae PETcu, Preoți hunedoreni pătimitori în temnițele comuniste, Cluj-Napoca, Edit. Argonaut - Deva, Edit. Episcopiei Devei și Hunedoarei, 2016, p. 20-115 etc.

${ }^{3}$ Cristian VASILE, Biserica Ortodoxă Română în primul deceniu comunist, Bucureşti, Edit. Curtea Veche, 2005, p. 110, 232-244.

${ }^{4}$ The cited documents were reported and made available through the courtesy of Mr. Adrian Nicolae Petcu from Bucharest, a well-known researcher of the Romanian 
is worth noting that his sufferings are too little known; in the specialty literature, until recently ${ }^{5}$ no reference was made about him, on the foreground being the presentation of the biography of priests arrested and imprisoned, many of whom perished in the communist labour colonies and prisons, which were in fact extermination camps of Romanian intellectuals. Just as little known is the dedication to priests of Patriarch Justinian Marina (1948-1977) and Bishop Andrei Magieru of Arad (19361960), the first falsely called the 'Red Patriarch', and the latter blamed for removal of the well-known confessor Arsenie Boca from the famous monastery of Prislop, Hunedoara County.

About priest George Zemora, it is known that he was born on February 25, 1901 in the village of Sebeșel - home of the more famous realist painter, graphic artist and book illustrator Sava Henţia (1848-1904) - from Săsciori Township, Alba County. After primary and secondary schoolin Alba Iulia, he graduated from the Normal School in Sibiu (19161920). He then practiced as a teacher for a short time (1920-1921) in the same locality. During 1921-1925, he attended the prestigious Theological Academy of Sibiu, was ordained in 1925, first deacon, then priest. He served for a while - probably - as a confessor priest in one of the schools in the Archdiocese of Sibiu. In August 1929, he was appointed, and then installed, as a priest-parish in the Orthodox Parish of Vulcan I (with Coroieşti filial) in the south of Hunedoara County. He pastored there for over two decades, until March $1951^{6}$.

In Vulcan, an important mining centre of the Jiu Valley, he cared closely for the beautiful church - dedicated to 'Saint Nicholas' - where he served, an edifice raised between 1907-1914 and 1919-1921 ${ }^{7}$, through the care of priests Sebastian Stanca $(1878-1947)^{8}$, and Sebastian Rusan

concentration camp phenomenon in mid twentieth century, whom I thank in this way.

${ }^{5}$ A. N. PETCU, op. cit., p. 111-114 (sources: Archives of the Archdiocese of Arad, file III-

213-1948; Archive of the National Council for Studying the Security Archives,

"Criminal" fund, file 74.112; IDEM, "Information" fund, file 867.234); Florin DOBREI,

"Viața bisericească în satul Lunca - istorie și actualitate", in Florin ILIEș (ed.), Lunca (Nevoieș) - repere monografice, Cluj-Napoca, Edit. Argonaut, 2016, p. 145-148.

${ }^{6}$ A. N. PETCU, op. cit., p. 111-112.

7 Arhiva Mitropoliei Ardealului, fond „Protopopiatul Ortodox Român Jiu”, dosar I89/1927; Florin DoBreI, Bisericile ortodoxe hunedorene, Reșița, Edit. Eftimie Murgu, 2011, p. 134.

${ }^{8}$ Parish in Vulcan (1907-1911), then adviser of the Diocese of Vad, Feleac and Cluj 
(1884-1956) ${ }^{9}$. Here he purchased a house which he renovated and furnished as a rectory. Similarly, in the nearby village of Dealu Babii, a vacant parish that he managed between 1929 and 1937, he built the premises of current primary school ${ }^{10}$.

In an interwar Jiu Valley undergoing economic, demographic and cultural boom, priest George Zemora, along with other Romanian clergy strove to raise the cultural level of his parishioners, to be a beacon and a real spiritual guiding benchmark ${ }^{11}$, both as a priest in the pulpit of the church in Vulcan and as a teacher of religion in the schools there. After 1948, with the removal of this school subject from the timetable, the worthy priest, despite the restrictions of the new 'regime of popular democracy' taught catechism lessons to students - every Sunday afternoon - in the place of worship, forming, with their help, a muchappreciated church choir ${ }^{12}$.

\section{The passions of priest George Zemora}

But times became troubled. On December 31, 1947, priest George Zemora was detained by security, "as part of the general measures of screening". Following the intervention of Metropolitan Nicolae Bălan of Transylvania (1920-1955) to the Minister of Internal Affairs, Teohari Georgescu, he was released on February 3, 1948. Catechization of the youth and organization of the church choir would now constitute serious charges. In October 1949, the militia prevented him from exerting his intense pastoral activity and from receiving any goods from believers, on account of those customary 'revenues of the epitrachelion' due to the parish. Receiving then - inevitably - the label of "hostile element towards

(1919-1940). Cf. Mircea PĂCURARIU, Dicționarul teologilor români, $3^{\text {rd }}$ ed., Sibiu, Edit. Andreană, 2014, p. 605-606.

${ }^{9}$ Parish in Vulcan (1912-1929), then bishop of Maramureş (1947-1948), archbishop of Suceava and Maramureş (1948-1950) and metropolitan of Moldova (1950-1956). Cf. Ibidem, p. 569.

10 Mircea BARon / Petru Hodor (ed.), Vulcan. Schițe monografice, Vulcan, Edit. Realitatea Românească, 2003, p. 216; Traian Moșıc, Din cele trăite printre oamenii de la izvoarele Jiului, Constanța, Ex Ponto, 2009, passim.

${ }^{11}$ Mircea BARon, Cărbune şi societate în Valea Jiului. Perioada interbelică, Petroşani, Edit. Universitas, 1998, passim.

12 A. N. Petcu, op. cit., p. 112. 
the working class" for the appeal he had among believers in an area eminently made up of workers, they went on to compromise him. Since May 1950, for several months, several Hebrews, former Communist 'illegals' and members of the Hebrew Democratic Committee (satellite organization of the Romanian Workers' Party) were questioned, who, in their statements, similar in content and language, argued that during the Legionary rebellion of January 1941, priest George Zemora made the basement of his house available for them to be investigated; yet, the charges could not be proven. Nevertheless, following the order of the Deputy Minister of Internal Affairs, Marin Jianu, on the night of 22 to 23 March, 1951 priest George Zemora together with his young daughter, Doina, a student in the tenth grade, were placed under house arrest in the township of Mănăstirea (renamed Alexandru Sahia) in Călărași County ${ }^{13}$.

The retention of priest George Zemora was announced to the Diocesan Centre of Arad by Archpriest Gheorghe Iacob of Petroșani on March 29, 1951 ${ }^{14}$. On March 30, 1951, the 'banished' priest presented his situation in a few epistolary lines:

"Your Eminence, I, undersigned priest George Zemora of Vulcan, Petroșani district, with filial obedience, report the following to Your Holiness. On the night of 22 to 23 March current year, I was taken with my daughter Doina ( $10^{\text {th }}$ grade, high school) to the police and then, on the same night, to Petroșani, from where, by train then by car, together with several other families, we were sent to the township of Mănăstirea, Olteniţa district, Bucharest region, where we arrived on 25 March current year, in the morning. My wife remained seriously ill at the state hospital in Vulcan, and the rectory, with all its contents alone and stray. On March 28 we were employed at the State Farm in Manastirea. I do not know the reason for our arrest and change of residence because I do not feel guilty of any deed that could have attracted such heavy penalty. I ask Your Holiness with filial obedience to give me guidance so as to work towards lifting this sanction"15.

In fact, the reason for his 'exile' according to the authorities was that during 1939-1941 he "carried out intense Legionary activity and was

${ }^{13}$ Ibidem, p. 112-113.

${ }^{14}$ Archive of Arad Archbishopric (hereinafter: AAA), III-213/1948, p. 344.

15 Ibidem, p. 370. 
part of the secret nest of intellectuals" although - it was mentioned in the investigation file - no documents could be found in this regard; his legal situation was regulated only by decision of the Ministry of Internal Affairs no. 200/1951 ${ }^{16}$.

At the top of the first page of the letter mentioned above sent by priest Zemora, bishop of Arad Andrei Magieru would write down, on April 7, 1951, the following: "1.) We denounce the case to the Patriarchate, calling for intervention. 2.) We respond to priest G. Zemora that we stepped in, and we appointed priest dr. E. Suciu as parish administrator in the parish. 3.) We appoint Priest E. Suciu as parish administrator in Vulcan I and as caretaker of the house of Priest G. Zemora" 17 . Indeed, in three consecutive addresses forwarded, on April 10, 1951, to the Deanery Office of Petroșani, Romanian Patriarchate (in those years between the two upper ecclesiastical centres there was a constant correspondence about the fate of the priests arrested or relocated - by ruling house arrest - in other areas of the country) and, not least, to priest George Zemora, the bishop of Arad showed his interest in resolving this situation. Thus, in the response letter of the Diocese Centre, signed by Bishop Andrei Magieru of Arad and by diocesan secretary Petru Vancu, Archpriest Gheorghe Iacob was entrusted with the following task:

"Your Eminence will know that during the entire absence of priest George Zemora from the parish, I ordered that Vulcan parish should be managed by priest Eugen Suciu from Vulcan II parish, who is responsible for taking care of the parish house of Father George Zemora." 18

It was communicated to the Patriarchate Chancellery:

"Eminence, with brotherly love we inform you that priest George Zemora of Vulcan Parish, Petroșani district, Hunedoara region, was arrested on the night of March 22, current year, together with his daughter, and transported by Militia bodies in the village of Mănăstirea, Oltenița district, Bucharest region, where, within a few days, he was hired to work on the State Farm of that community. The above-mentioned priest told us that no explanation was given regarding this change of residence and that he did not feel guilty of any deed that could have entailed a punishment

${ }^{16}$ A. N. PeTCU, op. cit., p. 113.

17 AAA, III 213/1948, p. 370.

${ }^{18}$ Ibidem, p. 371. 
so severe. Taking into account that the situation of the above-mentioned priest is entirely unclear, please, Eminence, make the necessary arrangements before the relevant authorities to clarify the situation of priest George Zemora, to be able to know if this priest can remain in the clergy in the old parish, or if it is necessary to transfer him to another parish, in another region [...]."19

Ultimately, priest George Zemora was informed succinctly:

"With reference to your letter, Holiness, of March 30, current year, we inform you that we spoke to the Holy Patriarch, asking to take the necessary steps before the relevant authorities for clarification of your situation, Holiness" 20 .

Shortly, by letter no. 8.886 of April 20, 1951, the Ministry of Culture communicated to the Diocese of Arad that "priest George Zemora from Vulcan I parish, Petroșani district was suspended from the payroll until the situation is clarified, starting on March 23, 1951" "21.

On May 5, 1951, Patriarch Justinian Marina sent the explanatory report of this suffering priest to the Ministry of Internal Affairs with a request to resolve the situation. As the response was running late, after two weeks a new request was sent; this time again no official letter was received $^{22}$. Therefore, not seeing any change, on May 10, 1951, Archpriest Gheorghe Iacob of Petroșani submitted a new address to the Diocesan Centre of Arad, showing once again the plight of the relocated priest and his parish, which had remained deprived by his forced arrest ${ }^{23}$.

Therefore, on May 19, 1951, bishop of Arad Andrei Magieru intervened again by another letter to Patriarch Justinian Marina ${ }^{24}$.

But things dragged on further, which is why, in July 1951, the priest let the bishop of Arad know the following again:

"Due to cold and fatigue together with the harsh work here, having insufficient food, I got very sick. The result of the $\mathrm{x}$-ray examination, undergone in Oltenița, on May 7, current year, was TBC [tuberculosis],

\footnotetext{
${ }^{19}$ Ibidem, p. 369.

${ }^{20}$ Ibidem, p. 371.

${ }^{21}$ Ibidem, p. 374.

22 A. N. PETCU, op. cit., p. 113.

23 AAA, III 213/1948, p. 372.

${ }^{24}$ Ibidem, p. 373.
} 
with basal pleurisy. At the recommendation of the doctor I got an easy job, as a day guard. Despite the rest and treatment I follow, my health condition is getting worse, and even this job I do inappropriately. This is also due to the unfavourable climate here. Because of this, in early June this year I asked the Honoured General Directorate of the Militia to be transferred to a region with a more favourable climate, to be admitted to a nursing home or to be allowed to move in the village of Sebesel, Sebes district, Sibiu region, where my sister lives, where I could receive treatment. This application has not heard back yet. My wife, after six months in hospital in Vulcan, had to leave and move into a room at the rectory, where she had to treat her recently contracted disease, jaundice. But as the two families of engineers living in the house did not want to clear the room, my wife, accompanied by our son-in-law who had come expressly from Cluj, had to go to my sister in the village of Sebeșel. Because my sister, who is also suffering, cannot take care of my wife, I am determined to make a new application to the Honourable General Directorate of the Militia, asking with all existence, that they approve my transfer and that of my daughter in the village of Sebeșel, where my daughter could take care of me and my wife. In the event that this new application will not receive any result, it is necessary to send my wife back to hospital. To this end, to have free health care, I lack proof that I am a civil servant, which I do not know where and how I can get [...]. Manastirea, on July 19, 1951 [...]"25.

The Diocesan Centre of Arad answered promptly this time, too: "It is confirmed, officially, that priest George Zemora is appointed as a budget priest at Vulcan I parish, Petroșani district, with a monthly salary of 4.888 lei"26; the signatories, namely vicar Gheorghe Lițiu and diocesan advisor Coriolan Iacob handed on the same date, August 4, 1951, through the Romanian Orthodox Parish Office of Sebeșel a similar certificate to the priests ${ }^{27}$. However, at the end of 1951, priest George Zemora the budget support in question is withdrawn by the state; the Deanery Office of Petroșani is informed by the Diocese of Arad, on 17 December that the "Ministry of Culture, by decision no. 24.846/1951, withdrew priest George Zemora from Vulcan I parish from the budget, on December 1, 1951 , the salary of the above-mentioned priest being deposited into the

25 Ibidem, p. 345-346.

${ }^{26}$ Ibidem, p. 347.

${ }^{27}$ Ibidem, p. 348. 
ARS LITURGICA. From the Image of Glory to the Images of the Idols of Modernity

savings account of the Ministry of Culture since the date of its deposit until 30 November 1951",28.

More and more letters and official endeavours followed; priest Zemora asked the Ministry of Internal Affairs to be allowed to move to Cluj-Napoca, to his eldest daughter (in this matter, Metropolitan Sebastian Rusan of Moldova himself talked to Prime Minister Petru Groza, but with no avail), and the Diocesan Centre in Arad to be transferred to the service of any other parish in the Diocese Arad and Hunedoara or the Archdiocese of Sibiu. In fact, from the perspective of the authorities, on September 12, 1951 the file was closed ${ }^{29}$.

Thus, months and years passed without any change foreseen in the horizon. On June 16, 1953, Archpriest Gheorghe Iacob of Petroșani would re-inform: "Revered Diocesan Council, in accordance with your order no. 2194/1953, with great respect, I inform you that there are two priests from the Deanery of Petroșani detained by the state bodies". One of them was "Zemora George former [priest] at Vulcan I Parish, arrested and taken with house arrest, on March 24, 1951, to the village of Mănăstirea, Oltenița district, Bucharest region" 30 .

On June 15, 1954, priest George Zemora submitted a new petition, this time to the Presidium of the Grand National Assembly. This was rejected too, on the grounds that during 1939-1941 he "had engaged in intense legionary activity and was part of the secret nest of intellectuals" so they could not allow the " end of his domiciliary restrictions because he is the enemy of our regime and, if he returns, because of his influence on the believers, he could conduct unfavourable propaganda" 31 .

Another memorandum was addressed to Patriarch Justinian Marina:

"I come before Your Eminence with the confidence that a son has in his father, asking you, obediently, to kindly intervene where You will see fit, for my release. On 22 March current year [1955] four years have passed since the undersigned, former Romanian Orthodox priest in Vulcan, Petroșani district, Hunedoara region, was taken from the parish

${ }^{28}$ Ibidem, p. 341.

${ }^{29}$ A. N. PETCU, op. cit., p. 113.

30 AAA, III 213/1948, p. 150.

${ }^{31}$ A. N. PETCU, op. cit., p. 113-114. 
and brought to Manastirea, where I am today. Of the 11 displaced families, 6 families were released on April 1, 1954, 1 (one) family on December 10, 1954 and 1 (one) family on February 6, 1955. The three (3) remaining families are awaiting release, which may take a long time. It has been 4 years of hard physical and moral suffering, which only with God's help I could bear. My wife has been ill in clinics and nursing homes waiting for her lungs to be operated on, and my daughter, a student in Cluj, lacking material support and without an adviser, is waiting every day for me to be released in order to be helpful to them. A deep bitterness of the soul comes over me at the thought that I have had to suffer for so long, torn from my spiritual purpose and away from home, with a clear conscience that I have not done anything wrong, neither against my homeland nor against the current regime of popular democracy. My work not only in the religious field, but also in the social, economic, cultural and artistic realm is rooted in a deep love for the good and progress of the people. I tried to be a father not only to the faithful entrusted to my pastorate, but to all those who have asked me for help, either in one way or another. If God helps me to be released by the benevolent intervention of Your Eminence, I am decided not return to Petroșani district, but to settle in the region of Cluj, where my two daughters live [...]. Mănăstirea, on 28 March 1955. George Zemora ${ }^{32}$.

Only after the intervention of April 7, 1955 of Patriarch Justinian Marina, by Decision No. 5.642 of April 20, 1955, did the Ministry of Internal Affairs raise the domiciliary restrictions of priest George Zemora ${ }^{33}$.

\section{End of the road}

Established briefly - probably - in Cluj-Napoca, in the home of one of his two daughters, but faced with the inherent financial difficulties and a boundless thirst to serve again on Christ's field, in 1956, following further requests addressed to the bishop of Arad, through the courtesy and courage of bishop Andrei Magieru, he was reinstated as a priest in Lunca (Nevoieș) parish of Brad Deanery (Hunedoara County). Here he lived alone in a rented house, taking care, as far as the times allowed, of the old church dedicated to the feast of 'Annunciation', of the spiritual prosperity

\footnotetext{
32 Ibidem, p. 114.

${ }^{33}$ Ibidem.
} 
of his new believers, and of perpetuating the ancient traditions of the region. He is credited with erecting the wooden cross of the old cemetery of this village community which marks the site of the former altar of the former wooden church of the congregation ${ }^{34}$.

In the parish of Lunca, he was a pastor for only five years, until 1961, when, retired by request due to sickness, he left the settlement to an unknown destination. No year of death is kept in the records or in the memories of the locals.

\section{References}

1. *** Archive of Arad Archbishopric, III-213/1948 file.

2. *** Archive of Transylvania Metropolitan, "Romanian Orthodox Parish of Jiu" fund, file I-89/1927.

3. *** Martiri pentru Hristos, din România, în perioada regimului comunist, Bucureşti, Institutul Biblic şi de Misiune al Bisericii Ortodoxe Române, 2007.

4. BARON, Mircea, Cărbune şi societate în Valea Jiului. Perioada interbelică, Petroşani, Universitas, 1998.

5. BARON, Mircea / HODOR, Petru (ed.), Vulcan. Schițe monografice, Vulcan, Realitatea Românească, 2003.

6. BASA, Gabriel, "Preoţi, teologi şi călugări hunedoreni în închisorile comuniste", in Altarul Banatului, no. 4-6/2005, p. 68-85.

7. DOBREI, Florin, Bisericile ortodoxe hunedorene, Reșița, Eftimie Murgu, 2011.

8. DURĂ, Ioan, "Ierarhi ai Bisericii Ortodoxe Române îndepărtaţi din scaun şi trimişi în recluziune monastică de către autorităţile comuniste în anii 1944-1981”, in Altarul Banatului, no. 10-12/2002, p. 34-56.

9. IONIȚOIU, Cicerone, Victimele terorii comuniste. Arestaţi, torturaţi, intemniţaţi, ucişi. Dicţionar, Bucureşti, Maşina de scris, 2000.

10. Manea, Vasile, Preoţi ortodocşi în închisorile comuniste, $3^{\text {rd }}$ ed., Alba Iulia, Reîntregirea, 2004.

11. ManeA, Vasile / IONIȚOIU, Cicerone, Martiri şi mărturisitori ai bisericii din România (1948-1989). Biserica ortodoxă, $2^{\text {nd }}$ ed., ClujNapoca, Patmos, 1998.

${ }^{34}$ Information received from parish priest Alin Amos Iuga of Lunca (Hunedoara County) in April 2016. 
12. MoşıC, Traian, Din cele trăite printre oamenii de la izvoarele Jiului, Constanţa, Ex Ponto, 2009.

13. PĂCURARIU, Mircea, Dicționarul teologilor români, $3^{\text {rd }}$ ed., Sibiu, Edit. Andreană, 2014.

14. Petcu, Adrian Nicolae, Preoți hunedoreni pătimitori în temnițele comuniste, Cluj-Napoca, Edit. Argonaut - Deva, Edit. Episcopiei Devei și Hunedoarei, 2016.

15. VAsile, Cristian, Biserica Ortodoxă Română în primul deceniu comunist, Bucureşti, Curtea Veche, 2005.

16. VeSA, Pavel, Clerici arădeni și hunedoreni deținuți politici (19451989), Deva, Episcopia Devei și Hunedoarei, 2014. 